Kong. Res. J. 1(1) : 57-64, 2014

Kongunadu Arts and Science College, Coimbatore

\title{
A SURVEY OF USEFUL AQUATIC MACROPHYTES, AND ITS BIOLOGICAL SPECTRUM IN KURANDIKULAM, MELASANKARANKUZHI, KANYAKUMARI DISTRICT, TAMIL NADU, INDIA
}

\author{
Mary Kensa, $\mathbf{V}^{*}$. \\ PG and Research Centre, Department of Botany, S.T. Hindu College, \\ Nagercoil, Kanyakumari District, Tamil Nadu, India. \\ *E.mail : surejkensa@gmail.com.
}

\begin{abstract}
This paper pen down the survey of useful aquatic macrophytes, and its biological spectrum inKurandikulam, Melasankarankuzhi, Kanyakumari District, Tamil Nadu, India.
\end{abstract}

Keywords: Aquatic macrophytes, Biological spectrum, Kanyakumari.

\section{INTRODUCTION}

Plants are vital to the function of aquatic ecosystems for their role in providing food, oxygen and habitat for other organisms. Aquatic macrophytes respond to the changes in water quality and have been used as bioindicator of pollution (Tripathi and Shukla, 1991) and are frequently used to reduce different kinds of pollutants from polluted water. The growth of aquatic plants or macrophytes in aquatic ecosysystem has an important influence on both the structure and the processes that occur in the stream habitat. Studies on aquatic macrophytes are in its initial phase in South India and it requires immediate attention (Gopal and Zutchi, 1998; Udayakumar and Doss, 2010). Rivers, soil moisture and relatively shallow groundwater basins are the principal sources of water for human (Srivastavaet al., 2008). One percent of the world's surface is covered by various fresh water habitats including the ponds (Gleick, 1996). They support life of $7 \%$ of the estimated 1.8 million described species. Aquatic macrophytes can be used as a tool in the determination of pollution and nutrient level (Melzer, 1999) water quality and lake condition (Clayton and Edwards, 2006) trophic status of lakes (Palmer et al., 1992), pollutant degradation (Mccutchen and Scgnoor, 2003) and decontaminate waste water (Nahlik and Mitsch, 2006). Urbanisation, industrialisation and bursting human population are the major threats to the fresh water ecosystem. In the present study, an attempt has been made to investigate the qualitative aspects of the macrophytes of Kurandikulam, Thoppur, kanyakumari District. Moreover, the present study is the first attempt to document the macrophytic diversity of the Thoppur, Kanyakumari District.

\section{METHODOLOGY}

\subsection{Study Area:}

The study area Kurandikulam is located in Melasankarankuzhipanchayat. This pond is situated in northern part of the Melasankarankuzhi. The villages like, Kurandi, Vadalivilai, Kothavilai are surrounding this pond. Most of the people are coolies. Around 2000 people are depends this pond for their domestic purposes. Due to the anthropogenic activities, this pond area is shrined day by day.

An extensive floristic survey was conducted during the year June 2012 - November 2012. The plant specimens were collected to prepare herbarium specimens and authenticate their correct identities. The collected specimens were identified taxonomically with the help of available monographs, taxonomic revisions and floras (Gamble and Fischer, 1915-1935; Mohanan and Henry, 1994; Santhapu and Henry, 1994) and collected specimens were cross checked for correct identification at the Herbarium of Tropical Botanical Garden and Research Institute, Trivandrum, Kerala and Department of Botany, S.T. Hindu College, Nagercoil.

\section{RESULTS AND DISCUSSION}

In the present study, altogether 65 macrophytic species were recorded and species were grouped under different categories i.e, Marginal (30 species), sub-merged (9 species), floating (7 species) and emergent (19 species) recorded in the present study were distributed over genera and families. Dicots (37 species) were dominant (19 families) and covered $57 \%$ of the total number of macrophytic species. Monocots (28 species) (9 families) were next to dicots and covered $43 \%$ of the total plants. Algae, Bryophytes and Pteridophytes were poor in distribution and were represented by three species each. Scientific names and habitat status are given in Table- 1 . Table- 2 depicts the family wise distribution of genus and species and their percent composition and Table-3 
depicts the summary of Taxonomic data and Table 4 showed the habitat status (number wise) their uses in Table-5. Life form classification and the Biological spectrum of the identified plants were showed in Table 6, 7.

From the present study, it was evident that study area was clearly dominated by dicotyledons followed by the Monocots, but Algae, Bryophytes and Pteridophytes contributed only three species each.Out of 65 species, the family Cyperaceae had contributed 7 species and their percentage composition is $10.6 \%$. Asteraceae, Euphorbiaceae, Lamiaceae, Hydrocharitaceae and Charophyceae had 3 species and their percentage composition is $4.5 \%$. Convolvulaceae, Caesalpiniaceae, Poaceae, Salviniaceae, Polytrichaceae had two species and their percentage composition is $3 \%$. Boraginaceae, Capparaceae, Nelumbonaceae, Nymphaceae, Onagraceae, Papaveraceae, Sapindaceae, Scrophulariaceae, Araceae, Ceratophyllaceae, Lemnaceae, Postederiaceae, Potamogetonaceae, had one species each and their percentage composition $1.5 \%$. The diverse type of macrophytic forms recorded from the study area indicates that the selected area is very rich in plant diversity particularly in submerged and emergent species. EichhorniaCrassipes(free floating),Hydrillaverticillata (submerged) and Cynodondactylon (marginal) Cyperusrotundus (emergent), Commelinabenghalensis (emergent), Acalyphaindica(marginal) and Tridaxprocumbens (marginal) were the dominant species in the study area. The growth of both submerged and emergent species was governed to some extent by the magnitude and duration of water depth. Most of submerged species like Utriculariastellaris, Ceratophyllumdemersum, Potamogetonmalanius, Hydrillaverticillataand Nitella species grew luxuriantly in shallow water as light and nutrients are available in plenty.Rooted floating leaved plant likeLemna minor, Azollapinnata, Salvinianatans and Marchantiaalso favoured this study area. Emergent like Alternantherasessilis, Scopariadulcis, Marsileaquadrifoliand Ipomeaaquatica were recorded from continuously water logged area of the study area. Some of the emergent like Ecliptaalba, Euphorbia hirta and Cyperusiria were found on dry area near the study area.

In the present study, the Raunkiar's system of life form classification has been followed.The identified plants were categories as Phanerophytes, Chamaephytes, Hemicryptophytes, Geophytes and Cryptophytes. Presently observed species include 7.69\% Chamaephytes which showed -38.31 deviation from normal biological spectrum; $15.38 \%$ phanerophytes and showed deviation of +6.38 ; $6.15 \%$ Cryptophytes and exhibits a deviation of $+0.15 \%$; 3.07\% Hemi cryptophytes with a deviation of $-22.93 \%$; $67.69 \%$ Therophytes and the deviation from normal biological spectrum is +54.69 (Table -7). There are five plant species belongs to Chamaephytes (Polygonumglabrum, P. barbarum, Charazeylanica, C. Nitzii and Nitella hyaline). Forty four plant species belongs to Therophytes, ten species belongs to Phanerophytes, four belongs to Cryptophytes and two plants belongs to Hemicryptophytes (Ipomeaaquatica and Hydrillaverticillata) Table -6.

Aquatic weeds are classified according to various habitats which form their eco-environment and become conducive for their growth, reproduction and dissemination. In the present study, some of the identified plants are called as aquatic weeds. They are Nelumbonucifera, Ipomeaaquatica(Rooted floating weed), Cyperusrotundus, Commelinabenghalensis (emergent weeds), Cynodondactylon, Hydrillaverticillata, Azollapinnata (Free floating weeds). These aquatic weeds interface with the static and flow water system. They cause tremendous loss of water from water bodies. Diffuse growth of these weeds provides an ideal habitat for the development of mosquitoes causing malaria and some other diseases. These weeds also serve as vectors for disease causing organisms and can greatly reduce the aesthetic value of water bodies from a recreational point of view. Our study area is enriched with small fishes that are due to the presence of aquatic weeds, because they provide continuous supply of phytoplankton.

The vegetation of the various plant species were classified after Raunkiar's life forms classifications as modified by Ellengberg and MullerDombois (1967) and Muller-Dombois and Ellemberg (1974).The form, habitat and nature of cotyledons, life form of occurrence of each species were studied in the field. The biological spectrum for the area has been compared with the Raunkiar;s Spectrum (Raunkiar's 1934, Muller Dombois and Ellemberg 1974).

Comparison of the presently prepared life form spectrum with that of the Raunkiar's normal biological spectrum of world revealed that therophytes were most (67.69\%) higher than the normal spectrum and other life forms like phanerophytes (15.38\%) and Cryptophytes (6.15\%) are higher than the normal spectrum. Chamaephytes (7.69\%) and Hemicrypotophytes (3.07\%) were found less than the normal spectrum. Therophytes 
were recorded five times higher than the normal spectrum and they are the indicators of amount of biotic influence on the vegetation and develop especially in the area where vegetation has been disturbed by overgrazing (Singh and Ambasht, 1975). Barucha and Dave (1994) stressed that higher Therophytes are indicators of the magnitude of influence of man and animals on the habitat Saxena and Singh (1982) prepared the biological spectrum for Himalayan vegetation across different altitudes. According to Asri (2003) therophytes are the indicators of dry conditions and also attributed to human activities. Abd EL-Ghani and Abdel-Khalik (2006) noted that the increase in grazing pressure throughout the southern Mediterranean ecosystems leads to the occupation of the under stories by invasive therophytes and indicates hyperdegradition. Kapoor and Singh (1990) also gave a detailed account of the life forms pattern in the temperature grass lands of Shimla hills, Himachal Pradesh.

The Biological spectrum of study area showed divergence when compared with Raunkiar's normal spectrum depicting the thero-phanerophytic (Therophytes -67.69\%; Phanerophytes -15.38\%) plant climate of the region. The preponderance of therophytes in the area may be due to the reason that the therophytes are the ephemerals, which survive adverse seasons in the form of seeds and predominantly found in extremes of dry, hot or cold, conditions.

Grasses are widespread than any other family of flowering plants of the world and represented by 10,000 species 261 genera (Karthikeyan, 2005). As in the case of any aquatic ecosystem, monocots dominate the vegetation having more species diversity in contrast to terrestrial habitats. But in this study, dicots are dominant than the monocots. Even though dicots are dominant Poaceae (Grasses), Cyperaceae (sedges), Hydrocharitaceae and Commelinaceae with $2,7,3$ and 2 species respectively dominated the study area.

Cyperaceae with its wide range of distribution and habit adaptability found a place even in the Pre-Linnaean contribution. An analysis has revealed that most of the species of Cyperaceae belongs to Penninsularindia, while Kallingabrevifolius, cyperusrotundus, Pycreuspunilis, Maricuscompaitus etc., are cosmopolitan and Cyperuscompressus, C. iria, Fimbristylisdichotomaare pantropical, the rest are more or less restricted in distribution, and show a strong affinity to the flora of Tamil Nadu, India, South east Asia and China.
Several species of Cyperus and Fimbristylis are frequently found as weed and they have a very wide range of distribution in the tropics of India. The present study agrees with the finding of Rao and Varma (1982) that these plants are in the wide range of distribution.

Geographic distribution of terrestrial plant species is often limited by climatic factors, by competition with species that perform better under their local environment and by the reduced reproductive success of range limit populations (Garcia et al ., 2000). Moreover high proportion of widely distributed taxa among the aquatic plants may be due to uniformity of the aquatic environment, widespread clonally, high phenotypic plasticity, ecological factors and climate in particular. These factors are known to constrain the distribution of plant species, resulting in large vegetation zones (Walter, 1973). It can be argued that the rest of the species down come from the neighbouring phyto-geographical domains. Jordan (2001) point out that geographical barriers and patterns of long - distance dispersal are often referred to as contributes to the distribution of aquatic flora.

The utilization of aquatic associated macrophytes at a sustainable basis can only succeed if the surface water and aquatic ecosystems are properly managed. Surface water and wetlands, and consequently aquatic plants are constantly threatened by a number of factors which include: drainage of wetlands for crop production, stream channelization and flood control, housing development, solid waste and nutrient loading from domestic sewage and agricultural runoff. The domestic sewage and industrial waste adversely affect the quality of water and consequently the flora and fauna of the water bodies (Verma, 2002). The human activities alter the structure of surface water and give a selective advantage to one, or a few species which develop a large population, 'crowd' out other species and lower the total community productivity.

Aquatic plants are especially sensitive to changes (increases in nutrient concentration and to organic pollutants. The physico-chemical characteristics have been found to exert influences on the biological production in water bodies (Kaushiket al., 2002). The aquatic weeds, which are a common sight in any aquatic system, become a menace for water bodies. In many places deweeding is a big programme, so in such a situation, if we can harness the potential of the weeds for better 
utility in indigenous medicine we can conserve the diversity of macrophytic plant population.

The present study indicates that the studied areas are very rich in flora biodiversity and indigenous knowledge. The local people are dependent on these species not only for domestic uses (especially food, manure, raw-materials), but also to cure various diseases. According to collected information, only small quantities of some species are collected and sell in market. However, there are possibilities to enhance the income of the local communities, if properly managed the habitats and potential species in an integrated manner with the involvement of local people in planning and management of the resources. So it is recommended to initiate the activities, such as inventory of useful species, habitat characteristics, identification of potential species for various economic uses and formulation and implementation of plan of actions taking consideration of the needs of people and sustainable management of the wetlands.

When questioned about the changing status of the existing plants, our respondents mentioned that the alien and invasive species are spreading very fast in the water bodies impacting on the growth of the native species. Some species, especially species ofNelumbo, Nymphoides and Trapa are declined in abundance during the last decade. Priority should be focused on the conservation of the valuable native species and their habitats with the integrated management measures.

\section{CONCLUSION}

The present trend of uses of plant diversity in the study area indicated that the uses of plants and traditional practices will continue to play a significant role in the socio-cultural life of these village communities. But the trend of decline of the abundance of some very useful native species, increase of unsustainable anthropogenic practices and encroachments and spreading of invasive species show that action for conservation is urgently needed. Therefore, priority should be given to implement conservation activities with integrated approach for sustainable development.

Table 1. List of aquatic macrophytic species identified in the study area (Kurandikulam, Melasankarankuzhi, Kanyakumari District).

\begin{tabular}{|c|c|c|}
\hline $\begin{array}{c}\text { S. } \\
\text { No }\end{array}$ & Botanical Name & Habitat Status \\
\hline \multicolumn{3}{|c|}{ ANGIOSPERMS DICOTYLEDONS } \\
\hline & AMARANTHACEAE & \\
\hline 1 & AchyranthesasperaLinn. & Marginal \\
\hline 2 & AlternantherasessilisLinn. & Emergent \\
\hline 3 & AmaranthusspinosusLinn. & Marginal \\
\hline 4 & DigeramuricataL. & Marginal \\
\hline 5 & $\begin{array}{r}\text { GomphrenacelosioidesMart. } \\
\text { ASTERACEAE }\end{array}$ & Marginal \\
\hline 6 & TridaxprocumbensLinn. & Marginal \\
\hline 7 & PartheniumhysterophorusLinn. & Marginal \\
\hline 8 & $\begin{array}{l}\text { Eclipta alba Hassk. } \\
\text { BORAGINACEAE }\end{array}$ & Emerrgent \\
\hline 9 & $\begin{array}{l}\text { HeliotropiumindicumLinn. } \\
\text { CONVOLVULACEAE }\end{array}$ & Marginal \\
\hline 10 & Ipomoea aquaticaForsk. & Emergent \\
\hline 11 & $\begin{array}{l}\text { Convolvulus arvensisLinn. } \\
\text { CAESALPINIACEAE }\end{array}$ & Margianl \\
\hline 12 & Cassia occidentalisLinn. & Marginal \\
\hline 13 & Cassia toraLinn. & Marginal \\
\hline 14 & $\begin{array}{l}\text { CAPPARACEAE } \\
\text { Cleome viscosaLinn. } \\
\text { EUPHORBIACEAE }\end{array}$ & Marginal \\
\hline 15 & Euphorbia hirtaLinn. & Marginal \\
\hline 16 & Phyllanthus simplex Rertz. & Marginal \\
\hline 17 & $\begin{array}{l}\text { AcalyphaindicaLinn. } \\
\text { LAMIACEAE }\end{array}$ & Marginal \\
\hline 18 & Ocimum sanctum Linn. & Marginal \\
\hline 19 & AnisomelesmalabaricaLinn. & Marginal \\
\hline 20 & $\begin{array}{r}\text { Leucasaspera (willd.) Spreng. } \\
\text { MALAVACEAE }\end{array}$ & Marginal \\
\hline 21 & SidarhombifoliaLinn. & Marginal \\
\hline 22 & $\begin{array}{l}\text { Abutilon indicum (Linn). } \\
\text { NELUMBONACEAE }\end{array}$ & Marginal \\
\hline 23 & $\begin{array}{r}\text { NelumbonuciferaGaertn. Fruct. } \\
\text { NYMPHAEACEAE }\end{array}$ & Floating \\
\hline 24 & $\begin{array}{l}\text { NymphaeastellataWilld. } \\
\text { LENTIBULARIACEAE }\end{array}$ & Floating \\
\hline 25 & $\begin{array}{l}\text { Utriculariastellarislinn. } \\
\text { ONAGRACEAE }\end{array}$ & Submerged \\
\hline 26 & $\begin{array}{r}\text { Ludwigiahyssopifolia (G.Don) } \\
\text { PAPAVERACEAE }\end{array}$ & Floating \\
\hline 27 & $\begin{array}{l}\text { ArgemonemexicanaLinn. } \\
\text { POLYGONACEAE }\end{array}$ & Marginal \\
\hline 28 & PolygonumgrabrumWilld. & Emergent \\
\hline 29 & $\begin{array}{l}\text { PolygonumbarbatumLinn. } \\
\text { SOLANACEAE }\end{array}$ & Emergent \\
\hline 30 & SolanumnigrumLinn. & Marginal \\
\hline 31 & Solanumxanthocarpumschrad. & Marginal \\
\hline 32 & Datura metal L. & Marginal \\
\hline 33 & Physalis minima Linn. & Marginal \\
\hline
\end{tabular}




\section{SAPINDACEAE}

34 CardiospermumhalicacabumLinn. SCORPHULARIACEAE

35 Scopariadulcislinn. RUBIACEAE

36 Lantana camaraLinn.

37 ClerodendrumviscosumVent. MONOCOTYLEDONS-ARACEAE

38 ColocasiaesculentaLinn. CERATOPHYLLACEAE

39 CeratophyllumdemersumLinn. CYPERACEAE

40 MaricuscompaitusRetzius

41 PycreuspunilisL.

42 FimbristylisdichotomaL

43 CyperuscompressusLinn.

44 CyperusrotundusLinn.

45 CyperusiriaLinn.

46 Kallingabrevifolia Rott ball. COMMENLINACEAE

47 CommelinabenghalensisLinn.

48 CommenlinanudifloraLinn.

49 Lemna minor Linn. LEMNACEAE

\section{HYDROCHARITACEAE}

50 HydrillaverticillataLinn.

51 OtteliaalsinoidesLinn.

52 VallisnariaspiralisLinn. PONTEDERIACEAE

53 Potamogetonmalaianus Miquel POACEAE

54 CynodondactylonLinn.

55 ChlorisbarbataL.

THALLOPHYTA (ALGAE) CHAROPHYCEAE

56 CharazeylanicaWilld

57 CharanitziiSchw.

58 Nitella hyaline Agardh PTERIDOPHYTA-SALVINACEAE

59 Azollapinnata R. brown

60 SalvinianatansLinn.

MARSILEACEAE

61 MarsileaquadrifoliaLinn. SELAGINELLACEAE

62 Selaginellaspecies MARCHANTIACEAE

63 Marchantiaspecies POLYTRICHACEAE

64 Polytrichum commune 65 Polytrichumjuniperinum
Marginal

Emergent

Marginal

Marginal

Marginal

Submerged

Emergent

Emergent

Emergent

Emergent

Emergent

Emergent

Emergent

Emergent

Emergent

Floating

Submerged

Submerged

Submerged

Submerged

Marginal

Marginal

Submerged

Submerged

Submerged

Floating

Floating

Emergent

Emergent

Floating

Emergent Emergent
Table 2, Family wise distribution of aquatic macrophytes in the study area (Erattaikulam, Thoopur, Kanyakumari District).

\begin{tabular}{|c|c|c|c|c|}
\hline $\begin{array}{l}\text { S. } \\
\text { No }\end{array}$ & Family & $\begin{array}{c}\text { No. of } \\
\text { species }\end{array}$ & $\begin{array}{l}\text { No. of } \\
\text { genus }\end{array}$ & $\begin{array}{c}\% \% \\
\text { Composition }\end{array}$ \\
\hline 1 & Amaranthaceae & 5 & 5 & $7.6 \%$ \\
\hline 2 & Araceae & 1 & 1 & $1.5 \%$ \\
\hline 3 & Asteraceae & 3 & 3 & $4.5 \%$ \\
\hline 4 & Boraginaceae & 1 & 1 & $1.5 \%$ \\
\hline 5 & Caesalpiniaceae & 2 & 1 & $3.0 \%$ \\
\hline 6 & Capparaceae & 1 & 1 & $1.5 \%$ \\
\hline 7 & Ceratophyllaceae & 1 & 1 & $1.5 \%$ \\
\hline 8 & Charophyceae & 3 & 2 & $3.0 \%$ \\
\hline 9 & Commelinaceae & 2 & 1 & $3.0 \%$ \\
\hline 10 & Convolvulaceae & 2 & 2 & $3.0 \%$ \\
\hline 11 & Cyperaceae & 7 & 5 & $10.6 \%$ \\
\hline 12 & Euphorbiaceae & 3 & 3 & $4.5 \%$ \\
\hline 13 & Hydrocharitaceae & 3 & 3 & $4.5 \%$ \\
\hline 14 & Lamiaceae & 3 & 3 & $4.5 \%$ \\
\hline 14 & Lemnaceae & 1 & 1 & $1.5 \%$ \\
\hline 16 & Lentibulariaceae & 1 & 1 & $1.5 \%$ \\
\hline 17 & Malvaceae & 1 & 1 & $1.5 \%$ \\
\hline 18 & Marchantiaceae & 1 & 1 & $1.5 \%$ \\
\hline 19 & Marsileaceae & 1 & 1 & $1.5 \%$ \\
\hline 20 & Nelumbonaeceae & 1 & 1 & $1.5 \%$ \\
\hline 21 & Nymphaeaceae & 1 & 1 & $1.5 \%$ \\
\hline 22 & Onagraceae & 1 & 1 & $1.5 \%$ \\
\hline 23 & Papaveraceae & 1 & 1 & $1.5 \%$ \\
\hline 24 & Poaceae & 2 & 2 & $3.0 \%$ \\
\hline 25 & Polygonaceae & 2 & 1 & $3 \%$ \\
\hline 26 & Polytrichaceae & 2 & 1 & $3.0 \%$ \\
\hline 27 & Pontederiaceae & 1 & 1 & $1.5 \%$ \\
\hline 28 & Potamogetonaceae & 1 & 1 & $1.5 \%$ \\
\hline 29 & Rubiaceae & 2 & 2 & $3 \%$ \\
\hline 30 & Salviniaceae & 2 & 2 & $3.0 \%$ \\
\hline 31 & Sapindaceae & 1 & 1 & $1.5 \%$ \\
\hline 32 & Scrophulariaceae & 1 & 1 & $1.5 \%$ \\
\hline 33 & Selaginellaceae & 1 & 1 & $1.5 \%$ \\
\hline 34 & Solanaceae & 4 & 3 & $6.0 \%$ \\
\hline
\end{tabular}

Table 3. Taxonomic data of aquatic macrophytes of study area.

\begin{tabular}{ccccccc}
\hline & D & M & A & P & B & Total \\
\hline Families & 19 & 9 & 1 & 3 & 2 & 34 \\
Genera & 33 & 16 & 2 & 4 & 2 & 62 \\
Species & 36 & 19 & 3 & 4 & 3 & 65 \\
\hline
\end{tabular}

D - Dicots; M- Monocots; A - Algae; P - Pteridophytes; BBryophytes.

Table 4. Habitat status of the identified plants in the area.

\begin{tabular}{ccccc}
\hline Habitats & Marginal & Floating & Emergent & Total \\
\hline $\begin{array}{l}\text { Number } \\
\text { of plants }\end{array}$ & 30 & 7 & 19 & 65 \\
\hline
\end{tabular}


Table 5. Identified plants in the study area and its uses

\begin{tabular}{|c|c|c|}
\hline S.No & Name of the plants & Uses \\
\hline 1 & Alternantherasessilis(L.)DC. & $\begin{array}{l}\text { Whole plant used in conditions of kapha and pitta, burning } \\
\text { sensation, leprosy, skin disease, dysepesia, haemorrhoids and } \\
\text { fever. Leaf used in bone fracture, eye complaints, bite of rabid } \\
\text { dog, snakebite and night blind. }\end{array}$ \\
\hline 2 & CeratophyllumdemersumL & Whole plant used as a cooling agent and scorpion sting. \\
\hline 3 & CommelinabenghalensisL. & $\begin{array}{l}\text { The plant is useful to treat bedsores, breast sores and } \\
\text { pimples. It is also used to control Haemorrhages. }\end{array}$ \\
\hline 4 & CynodondactylonPers & $\begin{array}{l}\text { Leaf juice drunk to relieve body pain. Leaf juice mixed with } \\
\text { lime applied to cure inflammation. }\end{array}$ \\
\hline 5 & CyperusrotundusL. & $\begin{array}{l}\text { Root used in bowl complaints, diuretic, jaundice, sores and } \\
\text { wound. Bulb used in dysentery. }\end{array}$ \\
\hline 6 & EcliptaprostrataL. & $\begin{array}{l}\text { The whole plant is used to treat jaundice, liver and spleen } \\
\text { complaints, malaria, anti-fertility, ulcers and wounds. Roots } \\
\text { used as an antidote to snakebite. Plant is squeezed and boiled } \\
\text { with coconut oil, applied on the scalp is a good medicine for } \\
\text { preventing hair loss and dandruff. }\end{array}$ \\
\hline 7 & Ipomoea aquaticaforsk & Leaf juice used as a mild purgative and blood purifier. \\
\hline 8 & Ludwigiahyssopifolia(G.Don). & Leaves used to cure cuts, wounds and sores. \\
\hline 9 & Marsileaquadrifolia L. & $\begin{array}{l}\text { Whole plant is useful in psychopathy, opthalmis, diarrhoea, } \\
\text { cough, bronchitis, leprosy, skin diseases, dyspesia, } \\
\text { haemmorrhoides, fever and insomnia. }\end{array}$ \\
\hline 10 & NelumbonuciferaGaetn & $\begin{array}{l}\text { Whole plant is given in hyperdipsia, chloera, diarrhoea, } \\
\text { helminthiasis, vomiting and cardiac debility, flowers used as a } \\
\text { cardio tonic in fever and diseases of liver. Rhizome used in } \\
\text { treatment of piles. Seeds used as cooling medicine for skin } \\
\text { diseases. }\end{array}$ \\
\hline 11 & Nymphaeastellatawild. & Whole plant used as cardio tonic. \\
\hline 12 & Polygonumglabrumwild. & $\begin{array}{l}\text { Plants used as a febrifuge and the infusion of leaves in colic } \\
\text { pain. }\end{array}$ \\
\hline 13 & VallisneriaspiralisL. & Whole plant is used as a stomachic and for leucorrhoea. \\
\hline 14 & Eichhorniacrassipes(Mart.) Solms & The whole plant used as manure and for fattening pigs. \\
\hline 15 & Hydrillaverticillata(L.F.) & $\begin{array}{l}\text { It is eaten by some fishes and it is a good oxygenator. It is } \\
\text { suitable for aquaria. }\end{array}$ \\
\hline 16 & Otteliaalsinoides(L.) Pers. & $\begin{array}{l}\text { The fruits are eaten by children. The petioles and blades are } \\
\text { used as vegetables. }\end{array}$ \\
\hline 17 & PolygonumbarbatumL. & $\begin{array}{l}\text { The root is used as an astringent and cooling remedy. The } \\
\text { leaves and stalks is said to be used as a stimulating wash for } \\
\text { ulcers. }\end{array}$ \\
\hline 18 & UtriculariastellarisL. & $\begin{array}{l}\text { Ecologically the plant is a good oxygenator of water and is } \\
\text { used by fishes for food. }\end{array}$ \\
\hline 19 & VallisneriaspiralisL. & $\begin{array}{l}\text { Ecologically the plant is a good oxygenator of water and is } \\
\text { used by fish for food. }\end{array}$ \\
\hline
\end{tabular}


Table 6. Life form classification of the aquatic macrophytic species from the study area.

\begin{tabular}{|c|c|c|c|}
\hline Life Forms & Name of the Plants & $\begin{array}{c}\text { No.of } \\
\text { Species }\end{array}$ & $\begin{array}{c}\% \\
\text { Composition }\end{array}$ \\
\hline Chamaephytes (CH & $\begin{array}{l}\text { lygonumglabrum, P.barbatum, Charazeylanica, } \\
\text { C.Nitzii, Nitella hyaline. }\end{array}$ & 5 & 7.69 \\
\hline Phanerophytes (P) & $\begin{array}{l}\text { iculariastellaris, Azollapinnata, Salvinianatans, } \\
\text { Ceratophyllumdemersum, Marsileaquadrifolia, } \\
\text { Lemna minor, Marchantiaspecies, Nelumbonucifera, } \\
\text { Nymphaeastellata, Ludwigiahyssopifolia. }\end{array}$ & 10 & 15.38 \\
\hline Cryptophytes (C) & $\begin{array}{l}\text { Vallisneriaspiralis, } \\
\text { Potamogetonmalaianus, Otteliaalsinoides. }\end{array}$ & 4 & 6.15 \\
\hline Therophytes (T) & 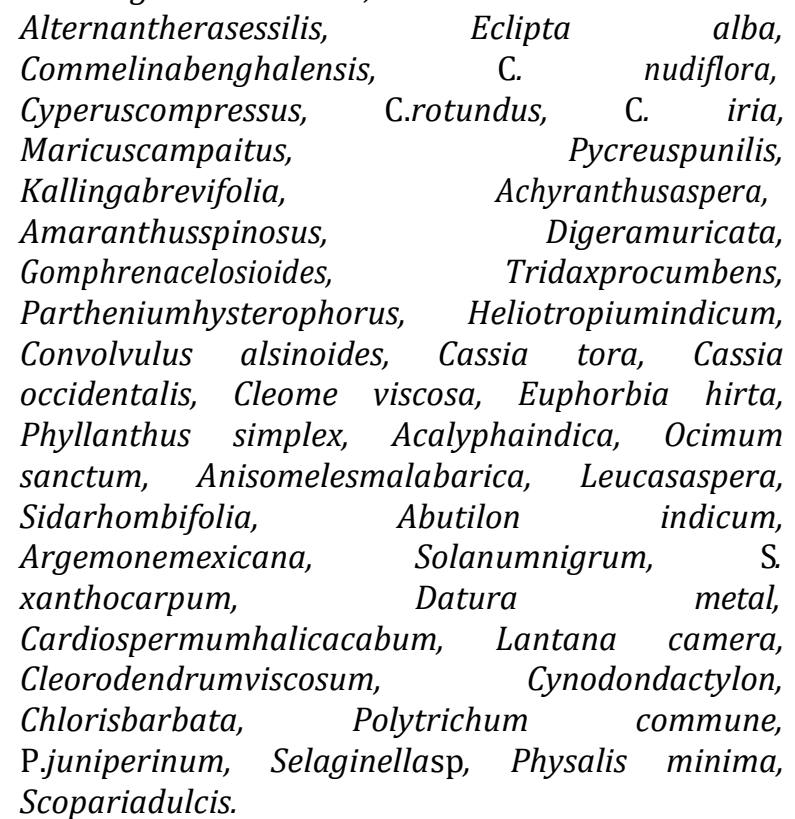 & 44 & 67.69 \\
\hline $\begin{array}{l}\text { Hemicryptophytes } \\
\text { (H) }\end{array}$ & Ipomoea aquatica, Hydrillaverticillata. & 2 & 3.07 \\
\hline
\end{tabular}

Table 7. Biological spectrum (\%) of all life forms found in the study area.

\begin{tabular}{lcccc}
\hline $\begin{array}{c}\text { Life Form } \\
\text { Classes }\end{array}$ & $\begin{array}{c}\text { No. of } \\
\text { Species }\end{array}$ & $\begin{array}{c}\text { Life forms (\%) } \\
\text { Present study }\end{array}$ & $\begin{array}{c}\text { Raunkiar's normal spectrum } \\
\text { and composition (\%) }\end{array}$ & $\begin{array}{c}\text { Deviation of Normal } \\
\text { Spectrum }\end{array}$ \\
\hline $\mathrm{Ch}$ & 5 & 7.69 & 46 & -38.31 \\
$\mathrm{PH}$ & 10 & 15.38 & 9 & 46.38 \\
$\mathrm{C}$ & 4 & 6.15 & 6 & +0.15 \\
$\mathrm{H}$ & 2 & 3.07 & 26 & -22.93 \\
$\mathrm{Th}$ & 44 & 67.69 & 13 & +54.69 \\
\hline Total & 65 & 100 & 100 & \\
\hline
\end{tabular}

Ch - Chamaephytes; C - Cryptophytes; H - Hemicryptophytes; Th - Therophytes; P-Phanerophytes

\section{REFERENCES}

Abd EL-Ghani and F.Abdel-Khalik, (2006). Aquatic and wetland plants in India.Oxford University press. United Kingdom; 1 - 385. Mathew, K.M., An excursion flora of central Tamil Nadu. Tamil Nadu: Thiruchirapalli, Rapinat Herbarium 1991; 1 - 682 .
Asri, K. (2003). Hand-book of common water and marsh plants of India and Burma. Govt. press. Delhi.

Barucha, C.H., and B.M. Dave, (1994). Floristic distribution and Life form Analysis of Sanapat Lake, Manipur. Indian J. Environ and Ecoplan. 6(1): $155-162$.

Clayton, J. and T. Edwards, (2006). Aquatic plants as environmental indicators of ecological 
condition in New Zealand lakes. Hydrobiologia. 570: $147-151$.

Ellenberg, H., and D.Muller-Dombois, (1967). Akey to Raunkiarplamt life forms and revised subdivisions.BerGeobot. Inst. ETH shifty Ruble, Zurich, 37: 56 - 73.

Gamble, J.S. and C.F.C. Fischer, 1915 - (1935). Flora of the presidency of Madras (Vol 1 - 3) London: Ablord and sons Ltd. 1389.

Garcia, W.D., V. Seshvatharam and P.Venu, (2000). Distribution of Aquatic vegetation as measured by Line intercept with Scuba Ecology, 46(6): 816-823.

Glieck, P.H. (1996). Water Resources. In: S. H. Schnidereds. Encyclopaedia of climate and weather. Oxford university press, New York, USA: $817-823$.

Gopal, B. and D.P. Zutchi, (1998). Fifty years of hydrobiological research in India. hydrobiological; 384: 267 - 290.

Jordon, B.K. (2001). Architecture and above ground production of a grassland community at Jhansi, India. Int. J. Ecol. Environ. Sc. 9:111-122.

Karthick, R. (2005).Community architecture of macrophytes in Hokarsur Wetland, Kashmir, Indian J. Environ.And Ecoplan. 10(3): 563-573.

Kaushik, K.R., D. Pandey, and R.S. Ambasht, (2002). Productive status of marsh zone vegetation of Geyar lake (Khetasalai) Jaunpur, India pp29-34. In: B. Gopal, R. E. Turner. R. G. Wetzct and D. F. Wingham (Eds.) Wetland Ecology and Management.National Institute and International Scientific Publications, India.

Kirtikar, K.R. and B.D. Singh, (1990), Indian Medicianal Plants, (Bishen Singh Mahendra Pal Singh, Dehradun).

Mccutcheon S.C. and J.L. Schnoor, (2003).Overview of phytotransformation and control of wastes In: Mccutcheon SC, Schnoor JL. eds. Phytoremediation: Transformation and control of contaminants, new York, wiley and sons. 358.

Mohanan, M. and A.N. Henry, (1994). Flora of Thiruvananthapuram, Trivandrum: Botanical survey of India. 621.
Muller Dombois, D., and H. Ellenberg, (1974). Aims and methods of vegetation Ecology.John wiley and sons, New York.

Nahlik A.M. and W.J. Mitsch, (2006). Tropical treatment wetlands dominated by free-floating macrophytes for water quality improvement incosta Rica. Ecol. Eng. 28: 246 - 25.

Palmer M.A.S., S.L. Bell and I. Butterfield, (1992). A botanical classification of standing water in Britain: applications for conservation and monitoring. Aquatic sonserv: Mar. Freshw. Ecosyst 2: 125 - 143.

Rao, P. and N.Verma, (1982).Medicinal plants. In: The natural resources of Kerala, by BalachandranThampi, Nair NM and Nair, C. S. WWF-India.

Raunkiaer, C. (1934). The life forms of plants. Statistical plant Geography. Clarendon press, Oxford.

Saxton, W.T. and L.J. Sedgwick, (1918 - 1922).Plants of Northern Gujarat. 6: 209 - 323, 1918, 9: 251 $-262,1922$.

Singh, A.K. (2006). A contribution to the aquatic and wetland flora of Varanasi. J. Econ. Taxon. Bot. 30 (1): $6-24$.

Singh, A.K., R .K. Panday and S. Singh, (1995).Understanding wetlands. Everyman's science XLI (2): 116 - 119.

Srivastava, J., A. Gupta and H. Chandra, (2008).Managing water quality with aquatic macrophytes. Rev. Environ. Sci. Biotechnol 7: $255-266$.

Tripathi, B.D. and S.C. Shukla, (1991). Biological treatment of waste water by selected aquatic plants. Environ - Poll 6: 69 - 78.

Udayakumar, M. and K. Ajithadoss (2010). Angiosperms \& Hydrophytes of five ephemeral lakes of Thiruvullur District, Tamil Nadu, India. Check list 6(2): 270 - 274.

Verma, J.P. (2002). Algae as ecological indicators of water quality. In: Aravindkumar (ed.) Ecology of polluted water. A. P. H. publishing corporation, New Delhi. 454-455.

Walter, H. (1073).Vegetation o the Earth in Relation to climate and the Ecophysiological conditions. London: English Universities press. 237. 